University of Nebraska - Lincoln

DigitalCommons@University of Nebraska - Lincoln

\title{
Post-Clovis survival of American Mastodon in the southern Great Lakes Region of North America
}

Neal Woodman

USGS Patuxent Wildlife Research Center, woodmann@si.edu

Nancy Beavan Athfield

National Isotope Center, n.beavan@gns.cri.nz

Follow this and additional works at: https://digitalcommons.unl.edu/usgsstaffpub

Woodman, Neal and Athfield, Nancy Beavan, "Post-Clovis survival of American Mastodon in the southern Great Lakes Region of North America" (2009). USGS Staff -- Published Research. 625.

https://digitalcommons.unl.edu/usgsstaffpub/625

This Article is brought to you for free and open access by the US Geological Survey at DigitalCommons@University of Nebraska - Lincoln. It has been accepted for inclusion in USGS Staff -- Published Research by an authorized administrator of DigitalCommons@University of Nebraska - Lincoln. 
Short Paper

\title{
Post-Clovis survival of American Mastodon in the southern Great Lakes Region of North America
}

\author{
Neal Woodman ${ }^{\mathrm{a}, *}$, Nancy Beavan Athfield ${ }^{\mathrm{b}}$ \\ a USGS Patuxent Wildlife Research Center, National Museum of Natural History MRC-111, Smithsonian Institution, Washington, DC 20013-7012, USA \\ ${ }^{\mathrm{b}}$ Rafter Radiocarbon, National Isotope Center, GNS Science, PO Box 31 312, Gracefield, Lower Hutt, New Zealand
}

\section{A R T I C L E I N F O}

Article history:

Received 9 July 2008

Available online 5 August 2009

\section{Keywords:}

Accelerator mass spectrometer

Extinction

Indiana

Mammut

Paleoindian

Radiocarbon

\begin{abstract}
A B S T R A C T
The end of the Pleistocene in North America was marked by a wave of extinctions of large mammals, with the last known appearances of many species falling between ca. $11,000-10,000{ }^{14} \mathrm{C} \mathrm{yr}$ BP. Temporally, this period overlaps with the Clovis Paleoindian cultural complex $\left(11,190-10,530{ }^{14} \mathrm{C}\right.$ yr BP) and with sudden climatic changes that define the beginning of the Younger Dryas chronozone (ca. $11,000-10,000{ }^{14} \mathrm{C} \mathrm{yr} \mathrm{BP}$ ), both of which have been considered as potential proximal causes of this extinction event. Radiocarbon dating of enamel and filtered bone collagen from an extinct American Mastodon (Mammut americanum) from northern Indiana, USA, by accelerator mass spectrometer yielded direct dates of $10,055 \pm 40{ }^{14} \mathrm{C}$ yr $\mathrm{BP}$ and $10,032 \pm 40{ }^{14} \mathrm{C}$ yr BP, indicating that the animal survived beyond the Clovis time period and into the late Younger Dryas. Although the late survival of this species in mid-continental North America does not remove either humans or climatic change as contributing causes for the late Pleistocene extinctions, neither Clovis hunters nor the climatic perturbations initiating the Younger Dryas chronozone were immediately responsible for driving mastodons to extinction.
\end{abstract}

(c) 2009 University of Washington. Published by Elsevier Inc. All rights reserved.

\section{Introduction}

The end of the Pleistocene in North America was marked by the extinction of 35 genera of mammals, most of them of large body size (>44 kg; Grayson and Meltzer, 2003; Koch and Barnosky, 2006; Grayson, 2006, 2007). Although some consider the extinctions of most of these animals to have been coeval (e.g., Firestone et al., 2007), the last well-dated occurrences for many individual species and genera are prior to $18,000{ }^{14} \mathrm{C}$ yr BP (Grayson and Meltzer, 2003; Guthrie, 2003; Barnosky et al., 2004; Stuart et al., 2004; Grayson, 2006, 2007). At least 16 genera survived into the latest glacial times (Grayson, 2006, 2007), and critical analyses of the reliability of dates associated with remains of extinct North American megafauna (Meltzer and Mead, 1983, 1985; Grayson, 1991) indicate that the extinctions of those taxa were complete by ca. $10,000{ }^{14} \mathrm{C}$ yr BP, with the last appearances of some species as early as $10,500{ }^{14} \mathrm{C}$ yr BP (Stuart, 1991; Grayson, 2001) or even $10,800{ }^{14} \mathrm{C}$ yr BP (Meltzer and Mead, 1983, 1985).

For more than $40 \mathrm{yr}$, controversy has surrounded many aspects of this event, including the forces driving the extinctions and its timing (Martin and Wright, 1967; Martin and Klein, 1984). Hypotheses most commonly focus responsibility for the extinctions on either rapid overkill by Clovis Paleoindians or the climatic events that marked the

\footnotetext{
* Corresponding author. Fax: +1 2023571932.

E-mail addresses: woodmann@si.edu (N. Woodman),n.beavan@gns.cri.nz (N. Beavan Athfield).
}

end of the Pleistocene and beginning of the Holocene (Koch and Barnosky, 2006), although hyperdisease (MacPhee and Marx, 1997) and an extraterrestrial impact event (Firestone et al., 2007) also have their proponents. Securely dated Clovis sites fall into the narrow time span of 11,190-10,530 ${ }^{14} \mathrm{C}$ yr BP (Hamilton and Buchanan, 2007; see also Waters and Stafford, 2007), indicating that the Clovis time period was closely coincident with the terminal large mammal extinctions. There is clear evidence that Clovis hunters occasionally pursued and killed some large mammals, primarily mammoths (Mammuthus spp.) and the American Mastodon (Mammut americanum) (Graham et al., 1981; G. Haynes, 2002; Barnosky et al., 2004; Koch and Barnosky, 2006), and they have been portrayed as specialists in big game, most notably now-extinct Pleistocene large mammals (Martin, 1990; G. Haynes, 2002; Waguespack and Surovell, 2003; but see Cannon and Meltzer, 2004).

Abrupt environmental changes that define the beginning (ca. $11,000{ }^{14} \mathrm{C}$ yr BP) and the end (ca. $10,000{ }^{14} \mathrm{C}$ yr BP; Stuiver et al., 1995) of the Younger Dryas chronozone (YDC) also are closely linked temporally with the terminal Pleistocene extinctions (G. Haynes, 2002; C. V. Haynes 2008). On a global scale, the YDC represents a time of unique climatic conditions that in parts of North America were manifested as increased seasonality with higher summer and lower winter temperature extremes that resulted in vegetational associations having no modern analogs (Shuman et al., 2002; Grimm and Jacobson, 2004). Sudden climatic change accompanied by loss of habitat, changes in growing season, alteration of reproductive or migration cycles, and disruption of co-evolved 
ecosystems have been hypothesized as contributing to the ultimate demise of the Pleistocene large mammal fauna (Martin and Klein, 1984). Moreover, the "one-two punch" of Clovis hunting pressure and rapid climatic change working either sequentially or in concert also has been recognized as a potentially devastating combination of forces that could have resulted in the extinction of the Pleistocene megafauna (Robinson et al., 2005; Koch and Barnosky, 2006).

Recently, Firestone et al. (2007) reported on physical and chemical markers from 10 sites dated from about 12,400-13,090 cal yr BP that they interpret as evidence of airbursts and/or impacts of one or more comets over northern North America about 12,900 cal yr BP (ca. $10,900{ }^{14} \mathrm{C}$ yr BP). They hypothesize that the immediate and secondary effects (i.e., widespread fires) from this extraterrestrial impact event triggered abrupt climatic change and the onset of the YDC. The resulting environmental changes contributed to the demise of Clovis culture, reduction of the North American Paleoindian population, and the extinction of much of the late Pleistocene large mammal fauna of North America.

Finally, MacPhee and Marx (1997) proposed that one or more diseases carried by the first humans entering North America from the Old World, or the animals accompanying them, may have evolved supervirulent strains that devastated North American large mammal species which had previously had no exposure to them. Although empirical evidence suggests that disease may have contributed to the extinction of individual species under stress (Rothschild and Laub, 2006), the hyperdisease hypothesis does not rely upon specific timing of the extinction event, and we do not address it further.

Here, we present new radiocarbon dates from an American Mastodon that indicate that this species inhabited the southern Great Lakes region of North America after the end of the Clovis cultural complex and during the late YDC. The implication of these new dates is that this species was not brought to immediate extinction either by Clovis people or by rapid climatic changes accompanying the beginning of the YDC, regardless of whether the YDC was initiated by terrestrial or extraterrestrial events.

\section{Background}

The remains of an American Mastodon that has become known as the Overmyer mastodon were originally discovered in 1976 during the excavation of a drainage ditch through an agricultural field in a former peat bog ca. 14 km NW of Rochester, Fulton County, northern Indiana. The skeleton was excavated and preserved by a team from Earlham College, Richmond, Indiana, in 1978 and is permanently deposited in the paleontology collection of the Cincinnati Museum Center, Ohio (catalog number CMC \#VP-1). The remains were recovered from ca. $170-260 \mathrm{~cm}$ below the current land surface in a ca. 183-cm-thick organic marl that contained abundant mollusk shells and was deposited over glacial outwash plain sediments. The bone-bearing marl was overlain sequentially by a distinctive, $0.5-2 \mathrm{~cm}$-thick layer of pale, calcareous sand; ca. $85 \mathrm{~cm}$ of dark, peaty marl containing scattered mollusk shells; and ca. $85 \mathrm{~cm}$ of reddish-brown, fibrous peat, the uppermost portion of which was disturbed by cultivation (Woodman and Branstrator, 2008). The stratigraphic sequence at the Overmyer site is comparable to those reported from other mastodon and other megafaunal bog sites in northern Indiana (Gooding and Ogden, 1965; Jackson and Whitehead, 1986; Swinehart and Richards, 2001), and it is consistent with that of a small, mineralrich, open-water pond that succeeded through time to a fen, a peat bog, and a forested peatland (Swinehart and Parker, 2000).

The recovered skeleton of the Overmyer mastodon consists of 106 identifiable remains, making it $41-48 \%$ complete (Woodman and Branstrator, 2008). The cranium and mandible of the Overmyer Mastodon are complete, and the tusk alveoli are entire, although the tusks were not recovered. Features of the skull and dentition are consistent with those of a large, mature, female approximately equivalent in age to a ca. 32- to 36-year-old African Elephant. Most of the recovered skeleton was excavated directly from the marl, and these remains are excellently preserved. Most bones are entire with clear surface features. They exhibit no evidence of weathering, rodent gnawing, or carnivore chewing. It appears that these skeletal elements were submerged and buried quickly, and they remained buried until excavation. The scattered distribution of in situ remains is reminiscent of taphonomic patterns of mastodon skeletons described from other pond and bog sites in Indiana and Ohio (e.g., Thomas, 1952; Gooding and Ogden, 1965; Graham et al., 1983). The general pattern suggests that the mastodon laid on its right side, with the posterior lower than the anterior. A few of the mastodon remains (at least three ribs, two thoracic vertebrae, and numerous fragments of bones, including part of the right humerus) were found on the surface in the surrounding field, where they had been scattered by the machinery digging the drainage ditch. Missing from the skeleton are portions of the anterior and left limbs. These may have been scavenged, but they could have separated from the decomposing carcass and may now be located in an unexcavated portion of the former pond. Alternatively, many of the missing bones may have been located in the main area of the drainage ditch and were removed or destroyed by the excavation equipment.

Conventional ( $\beta$-decay counting) radiocarbon dating of wood recovered from ca. $15 \mathrm{~cm}$ beneath the pelvis of the mastodon and ca. $230 \mathrm{~cm}$ below the current ground surface provided a maximum date for the remains of $12,575 \pm 260{ }^{14} \mathrm{C}$ yr BP (UGa-2774). This date is comparable to the few other published radiocarbon dates for mastodons from this region recorded in the Faunmap database (Faunmap Working Group, 1994). It is also well before the Clovis time period, the Younger Dryas chronozone, and the postulated comet (Table 1).

Table 1

Uncalibrated $\left({ }^{14} \mathrm{C}\right.$ yr BP) and calibrated (cal yr BP) radiocarbon dates for late Pleistocene events and mastodons.

\begin{tabular}{|c|c|c|c|}
\hline Event & ${ }^{14} \mathrm{C}$ yr BP & cal yr BP & References \\
\hline \multirow[t]{3}{*}{ Clovis } & $11,500-10,900$ & $13,440-12,822$ & C. V. Haynes (2008) \\
\hline & $11,190-10,530$ & $13,106-12,255$ & Hamilton \& Buchanan (2007) \\
\hline & $11,080-10,765$ & $13,250-12,800$ & Waters \& Stafford (2007) \\
\hline Younger Dryas & $11,021-10,000$ & $12,890-11,650$ & Stuiver et al. (1995) \\
\hline Extraterrestrial impact & $10,940-10,890$ & $12,930-12,920$ & Firestone et al. (2007) \\
\hline Terminal extinction & $11,000-10,000$ & $12,950-11,340$ & $\begin{array}{l}\text { Grayson (2001), G. Haynes (2002), } \\
\text { Meltzer \& Mead (1983, 1985), Stuart (1991) }\end{array}$ \\
\hline Rappuhn mastodon & $10,750 \pm 400$ & $13,370-11,350$ & Kapp (1986) \\
\hline Pleasant Lake mastodon & $10,395 \pm 100$ & $12,680-11,840$ & Fisher (1984) \\
\hline \multicolumn{4}{|l|}{ Overmyer mastodon } \\
\hline wood & $12,575 \pm 260$ & $15,474-13,932$ & Woodman \& Branstrator (2008) \\
\hline MW-filtered collagen & $10,055 \pm 40$ & $11,801-11,347$ & NZA 29627 \\
\hline Enamel & $10,032 \pm 40$ & $11,749-11,330$ & NZA 29243 \\
\hline Unfiltered collagen & $9,863 \pm 40$ & $11,345-11,201$ & NZA 29236 \\
\hline
\end{tabular}

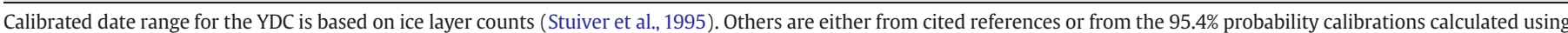
Calib 5.0.2 (Stuiver and Reimer, 1993). 


\section{Methods and results}

We recently obtained two new samples of the Overmyer mastodon from the Cincinnati Museum Center for radiometric dating. One ca. 500mg piece of vesicular bone from the mastodon's scapula was chemically pretreated and gelatinized (Beavan Athfield and Sparks, 2001). The resulting gelatinized collagen preparation was analyzed by accelerator mass spectrometer (AMS; Stafford et al.,1991) by the Rafter Radiocarbon Laboratory, GNS Science, New Zealand, yielding a date of $9863 \pm 40{ }^{14} \mathrm{C}$ yr BP (NZA 29236; Table 1; Appendix). A sample of ca. $500 \mathrm{mg}$ of molar enamel was pretreated with a $0.5 \mathrm{M} \mathrm{HCl}$ acid wash, and the etched enamel was then rinsed with deionized water, dried, and pulverized to $<0.75 \mu \mathrm{m}$. Acid hydrolysis was performed on the pretreated enamel $\left(\mathrm{CO}^{2}\right.$ evolution) by mixing $0.64 \%$ orthophosphoric acid with the powdered enamel in an evacuated side-arm flask, and reacting to produce $\mathrm{CO}_{2}$. The $\mathrm{CO}_{2}$ was cryogenically distilled and graphitized to create a sample target for AMS analysis, which provided a date for the enamel of $10,032 \pm$ $40{ }^{14} \mathrm{C}$ yr BP (NZA 29243; Table 1; Appendix).

The standard errors of these two dates do not overlap, and the $\mathrm{C} / \mathrm{N}$ ratio (3.7; Table 2) of the bone collagen sample is marginally higher than the suggested $\mathrm{CN}$ range for modern bone protein (2.9-3.6; Deniro, 1985), suggesting the potential presence of more recent carbon (Minami and Nakamura, 2005). Therefore, a second sample of the bone protein fraction, consisting of the remainder of the gelatinized collagen, was further processed through a pre-cleaned (Higham et al., 2006) molecular weight (MW) filter at a $30 \mathrm{kDa}$ cutoff (Vivaspin $15^{\mathrm{TM}}$, Sartorius Stedim Biotech) to remove possible low-molecularweight, exogenous carbon contaminants. These MW-separation filters remove lower molecular-weight contaminants such as salts, degraded collagen fragments, and low-molecular-weight soil-derived contaminants including humic and fulvic acids. They preferentially retain molecular weights of $60,000 \mathrm{Da}$ and above, thereby concentrating whole, undegraded protein with a molecular mass of $\approx 97-110 \mathrm{kDa}$. AMS analysis of the MW-filtered collagen yielded a second date on protein of $10,055 \pm 40{ }^{14} \mathrm{C}$ yr BP (NZA 29627; Appendix). The close agreement of the date on the MW-filtered collagen and the date on the enamel $\left(X^{2}=0.142, P_{\mathrm{df}=1}>0.5\right.$; Appendix $)$ suggests that a younger contaminant was removed from the bone protein by the filtration and that these two results on enamel (NZA 29243) and filtered collagen (NZA 29627), processed by different chemical methods, most closely represent the true depositional age of the mastodon.

\section{Discussion}

The new AMS dates are $>2500{ }^{14} \mathrm{C}$ yr younger than the previous conventional date on wood recovered from below the skeleton of the Overmyer mastodon, and they provide more direct determinations of its age. The discrepancy between the wood date and the AMS dates may be attributed to the skeleton settling into older bog sediments; to a low relatively low rate of sedimentation; or to disturbance and mixing of the pond sediments, either by the animal itself or by other organisms in the immediate environment. At its best, the wood date represents a maximum age for the mastodon. Our new results emphasize the importance of direct AMS dating of remains of late Pleistocene mammals previously dated from associated materials.

Our ages of $10,055{ }^{14} \mathrm{C}$ yr BP for MW-filtered collagen and $10,032{ }^{14} \mathrm{C}$ yr BP for enamel from the Overmyer mastodon are several hundred years younger than other radiocarbon dates previously reported for American Mastodon, including $10,395 \pm 100{ }^{14} \mathrm{C}$ yr BP for the Pleasant Lake mastodon and $10,750 \pm 400{ }^{14} \mathrm{C}$ yr BP for the Rappuhn mastodon, both from Michigan (Table 1; Meltzer and Mead, 1983, 1985; Stuart, 1991). The age of the Pleasant Lake mastodon was obtained using wood fragments removed from within the pulp cavities of both tusks (Fisher, 1984), which must have been deposited sometime after the animal died. That date therefore represents a minimum age for the individual. Wood samples from underneath the skeleton provided the date for the Rappuhn mastodon (Kapp, 1986), and as in the case of the wood date from the Overmyer mastodon, it represents a maximum age. Dates on both the Pleasant Lake and Rappuhn mastodons have large standard errors, indicating the relative imprecision of the age determinations.

The new dates on the Overmyer mastodon clearly indicate that the species existed in northern Indiana several centuries later than the last reliably dated Clovis sites, variously reported as either 10,765 $\pm 25{ }^{14} \mathrm{C}$ yr BP at the Jake Bluff site, OK (Waters and Stafford, 2007), or $10,530 \pm 103{ }^{14} \mathrm{C}$ yr BP for the Vail site, ME (Hamilton and Buchanan, 2007). Although these dates on the Overmyer mastodon do not indicate that humans were not responsible for the extinction of the American Mastodon or even that Clovis people did not impact the population, they do indicate that the species was not brought to extinction during the time of Clovis.

The species also survived nearly to the end of the YDC, indicating that neither the rapid climatic change that initiated this interval (Shuman et al., 2002) nor the hypothesized extraterrestrial trigger for the YDC (Firestone et al., 2007) brought about the immediate extinction of the North American Mastodon. Previous study of relative numbers of preserved spores of the dung fungus Sporormiella, used as a proxy for megafaunal biomass, suggests that populations of large mammals were in steep decline in northeastern North America before the onset of the YDC. Robinson et al. (2005) interpreted these data as supporting a mosaic model of extinction, with residual populations of large mammals in isolated areas, even as these species were extirpated from the broader landscape. Although our dates for the Overmyer mastodon are the youngest for this species, this does not indicate that it represented the last surviving mastodon or even the last surviving population (e.g., Signor and Lipps, 1982). The Overmyer mastodon lived and died at a time when the climate was warming and vegetational associations were changing rapidly (Shuman et al., 2002, 2005; Grimm and Jacobson, 2004; Wright, 2006), and while it may represent a similar "last stand" population surviving in the southern Great Lakes region, the only certainty is that the species was present in northern Indiana at that time.

A scenario of near-simultaneous megafaunal extinction at the end of the Pleistocene has already been challenged by the late survival of individual extinct species in outlying areas, especially islands (e.g., Veltre et al., 2008). Both the intensity of human occupation and the

Table 2

$\mathrm{C} / \mathrm{N}$ results and internal standards for pre-molecular weight separated scapular bone protein sample NZA 29236.

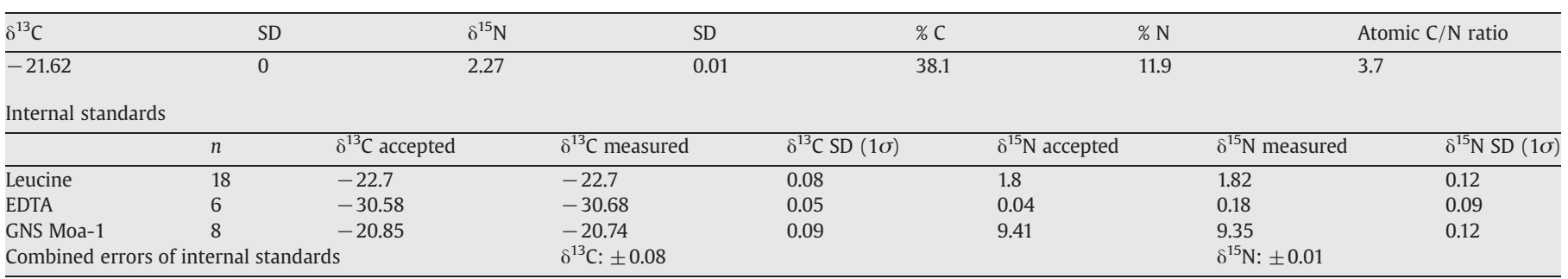


effects of the YDC appear to have varied across infraglacial North America (Shuman et al., 2002; Cannon and Meltzer, 2004). As more precise and accurate methods of dating are applied to additional sites, it should not be surprising to discover that the timing of the final extirpations of now-extinct large mammals also varied across the continent.

The southern Great Lakes and other regions of North America have yielded large numbers of remains of Pleistocene proboscideans and other extinct fauna (Faunmap Working Group, 1994). Unfortunately, relatively few remains or sites have been dated by radiocarbon methods; and, as was previously the case for the Overmyer mastodon, the majority of existing dates are older conventional dates on associated materials or on unfiltered bone collagen (Meltzer and Mead, 1985). Additional direct AMS dating of filtered samples from provenanced museum specimens will greatly enhance our ability to determine accurately the ages of organic remains, which are critical for understanding the timing, patterns, and causes of the late Pleistocene extinctions.

\section{Acknowledgments}

We are indebted to Glenn W. Storrs, Cincinnati Museum Center (CMC), for providing samples of the Overmyer mastodon for AMS dating. Kelly Sutton and staff of Rafter Radiocarbon processed the bone and enamel samples. Sandy Feinstein, Alfred L. Gardner, Russell W. Graham, and an anonymous reviewer provided helpful comments on previous versions of the manuscript. Any use of trade, product, or firm names is for descriptive purposes only and does not imply endorsement by the U.S. Government.

\section{Appendix. AMS radiocarbon dating statistics}

Radiocarbon age, $\delta{ }^{14} \mathrm{C}, \Delta{ }^{14} \mathrm{C}$, and absolute percent modern are used as defined by Stuiver and Polach (1977). Calibrated age ranges (95.4\% confidence interval) calculated using Calib 5.0.2 (Stuiver and Reimer, 1993) and Oxcal 3.10 (Bronk Ramsey, 2001), both based on atmospheric date from Reimer et al. (2004). A Chi ${ }^{2}$ test performed using Oxcal 3.10 indicates that the calibrated date ranges for samples NZA 29243 and NZA 29627 are not significantly different $\left(\chi^{2}=0.142\right.$, $\left.P_{\mathrm{df}=1}>0.5\right)$.

Sample NZA 29236, gelatinized scapular bone: $9863 \pm 40{ }^{14} \mathrm{C}$ yr BP (radiocarbon years before present, $0{ }^{14} \mathrm{C}$ yr $\mathrm{BP}=\mathrm{AD} 1950$ ); percent modern $=29.09 \pm 0.14 ; \delta{ }^{13} \mathrm{C}=-21.8 \% ; \quad \delta{ }^{14} \mathrm{C}=-707.2 \pm 1.5 \%$; $\Delta{ }^{14} \mathrm{C}=-709.1 \pm 1.4 \%$; calibrated age range: $11,345-11,201 \mathrm{cal} \mathrm{yr}$ BP (Calib 5.0.2).

Sample NZA 29243, molar enamel: $10,032 \pm 40{ }^{14} \mathrm{C}$ yr BP; percent modern $=28.48 \pm 0.14 ; \delta{ }^{13} \mathrm{C}=-10.6 \% ; \delta{ }^{14} \mathrm{C}=-706.7 \pm 1.4 \%$; $\Delta{ }^{14} \mathrm{C}=-715.2 \pm 1.4 \%$; calibrated age ranges (95\% confidence interval): $11,749-11,330$ cal yr BP (Calib 5.0.2); 11,760-11,330 cal yr BP (Oxcal 3.10).

Sample NZA 29627, molecular-weight-filtered gelatinized scapular bone: $10,055 \pm 40{ }^{14} \mathrm{C}$ yr BP; percent modern $=28.4 \pm 0.15 ; \delta{ }^{13} \mathrm{C}=$ $-21.7 \%$; $\delta{ }^{14} \mathrm{C}=-714.1 \pm 1.5 \%$; $\delta{ }^{14} \mathrm{C}=-716.0 \pm 1.5 \%$; calibrated age ranges (95\% confidence interval): 11,801-11,347 cal yr BP (Calib 5.0.2); 11,810-11,340 cal yr BP (Oxcal 3.10).

\section{References}

Barnosky, A.D., Koch, P.L., Feranec, R.S., Wing, S.L., Shabel, A.B., 2004. Assessing the causes of late Pleistocene extinctions on the continents. Science 306, 70-75.

Beavan Athfield, N., Sparks, R.J., 2001. Dating of Rattus exulans and bird bone from Pleasant River: radiocarbon anomalies from diet. Journal of the Royal Society of New Zealand 31, 801-809.

Bronk Ramsey, C., 2001. Development of the radiocarbon program OxCal. Radiocarbon 43, 355-363.

Cannon, M.D., Meltzer, D.J., 2004. Early Paleoindian foraging: examining the faunal evidence for large mammal specialization and regional variability in prey choice. Quaternary Science Reviews 23, 1955-1987.
Deniro, M.J., 1985. Postmortem preservation and alteration of in-vivo bone collagen isotope ratios in relation to palaeodietary reconstruction. Nature 317, 806-809.

Faunmap Working Group, 1994. Faunmap: a database documenting late Quaternary distributions of mammal species in the United States. Illinois State Museum Scientific Papers 25, i-viii, 1-690. (http://www.museum.state.il.us/research/faunmap/).

Firestone, R.B., West, A., Kennett, J.P., Becker, L., Bunch, T.E., Revay, Z.S., Schultz, P.H., Belgya, T., Kennett, D.J., Erlandson, J.M., Dickenson, O.J., Goodyear, A.C., Harris, R.S. Howard, G.A., Kloosterman, J.B., Lechler, P., Mayewski, P.A., Montgomery, J., Poreda, R., Darrah, T., Que Hee, S.S., Smith, A.R., Stich, A., Topping, W., Wittke, J.H., Wolbach, W.S., 2007. Evidence for an extraterrestrial impact 12,900 years ago that contributed to the megafaunal extinctions and the Younger Dryas cooling. Proceedings of the National Academy of Sciences 104, 16016-16021.

Fisher, D.C., 1984. Taphonomic analysis of late Pleistocene mastodon occurrences: evidence of butchery by North American Paleo-Indians. Paleobiology 19, 338-357.

Gooding, A.M., Ogden III, J.G., 1965. A radiocarbon dated pollen sequence from the Wells Mastodon site near Rochester. Indiana. Ohio Journal of Science 65,1-11.

Graham, R.W., Haynes, C.V., Johnson, D.L., Kay, M., 1981. Kimmswick: a Clovis-mastodon association in eastern Missouri. Science 213, 1115-1117.

Graham, R.W., Holman, J.A., Parmalee, P.W., 1983. Taphonomy and paleoecology of the Christensen Bog mastodon bone bed, Hancock County, Indiana. Illinois State Museum Reports of Investigations 38, 1-29.

Grayson, D.K., 1991. Late Pleistocene mammalian extinctions in North America: taxonomy, chronology, and explanations. Journal of World Prehistory 5, 193-231.

Grayson, D.K., 2001. The archaeological record of human impacts on animal populations. Journal of World Prehistory 15, 1-68.

Grayson, D.K., 2006. Late Pleistocene faunal extinctions. In: Ubelaker, D.H. (Ed.) Handbook of North American Indians. Vol. 3. Environment, origins, and populations. Smithsonian Institution, Washingon, DC, pp. 208-218.

Grayson, D.K., 2007. Deciphering North American Pleistocene extinctions. Journal of Anthropological Research 63, 185-213.

Grayson, D.K., Meltzer, D.J., 2003. A requiem for North American overkill. Journal of Archaeological Science 30, 585-593.

Grimm, E.C., Jacobson Jr, G.L., 2004. Late-Quaternary vegetation history of the eastern United States. In: Gillespie, A.R., Porter, S.C. (Eds.), The Quaternary Period in the United States. Elsevier, New York, pp. 381-402.

Guthrie, R.D., 2003. Rapid body size decline in Alaskan Pleistocene horse before extinction. Nature 426, 169-171.

Hamilton, M.J., Buchanan, B., 2007. Spatial gradients in Clovis-age radiocarbon dates across North America suggest rapid colonization from the north. Proceedings of the National Academy of Sciences 104, 15625-15630.

Haynes, G., 2002. The catastrophic extinction of North American mammoths and mastodonts. World Archaeology 33, 391-416.

Haynes Jr, C.V., 2008. Younger Dryas "black mats" and the Rancholabrean termination in North America. Proceedings of the National Academy of Sciences 105, 6520-6525.

Higham, T.F.G., Jacobi, R.M., Ramsey, C.B., 2006. Radiocarbon dating of ancient bone using ultrafiltration. Radiocarbon 48, 179-195.

Jackson, S.T., Whitehead, D.R., 1986. Late-glacial and early Holocene vegetational history at the Kolarik Mastodon Site, northwestern Indiana. American Midland Naturalist 115, 361-373.

Kapp, R.O., 1986. Late-glacial pollen and macrofossils associated with the Rappuhn Mastodont (Lapeer County, Michigan). American Midland Naturalist 116, 368-377.

Koch, P.L., Barnosky, A.D., 2006. Late Quaternary extinctions: state of the debate. Annual Review of Ecology, Evolution and Systematics 37, 215-250.

MacPhee, R.D., Marx, P.A., 1997. The 40,000-year plague: humans, hyperdisease, and first contact extinctions. In: Goodman, S.M., Patterson, B.D. (Eds.), Natural Change and Human Impact in Madagascar. Smithsonian Institution Press, Washingon, DC, pp. 169-217.

Martin, P.S., 1990. 40,000 years of extinctions on the "planet of doom". Palaeogeography, Palaeoclimatology, Palaeoecology 82, 187-201.

Martin, P.S., Klein, R.G., 1984. Quaternary Extinctions: A Prehistoric Revolution. University of Arizona Press, Tucson.

Martin, P.S., Wright Jr., H.E., 1967. Pleistocene Extinctions. The Search for a Cause. Yale University Press, New Haven.

Meltzer, D.J., Mead, J.I., 1983. The timing of late Pleistocene mammalian extinctions in North America. Quaternary Research 19, 130-135.

Meltzer, D.J., Mead, J.I., 1985. Dating late Pleistocene extinctions: theoretical issues, analytical bias, and substantive results. In: Mead, J.I., Meltzer, D.J. (Eds.) Environments and Extinctions: Man in Late Glacial North America. Center for the Study of Early Man, Orono, Maine, pp. 145-173.

Minami, M., Nakamura, T., 2005. Carbon and nitrogen isotopic fractionation in bone collagen during chemical treatment. Chemical Geology 222, 65-74.

Reimer, PJ., Baillie, M.G.L., Bard, E., Bayliss, A., Beck, J.W., Bertrand, C., Blackwell, P.G., Buck, C.E., Burr, G., Cutler, K.B., Damon, P.E., Edwards, R.L., Fairbanks, R.G., Friedrich, M., Guilderson, T.P., Hughen, K.A., Kromer, B., McCormac, F.G., Manning, S., Bronk Ramsey, C., Reimer, R.W., Remmele, S., Southon, J.R., Stuiver, M., Talamo, S., Taylor; F.W., van der Plicht, J., Weyhenmeyer, C.E., 2004. IntCal04 terrestrial radiocarbon age calibration, 0-26 cal kyr BP. Radiocarbon 46, 1029-1058.

Robinson, G.S., Burney, L.P., Burney, D.A., 2005. Landscape paleoecology and megafaunal extinction in southeastern New York state. Ecological Monographs 75, 295-315.

Rothschild, B.M., Laub, R., 2006. Hyperdisease in the late Pleistocene: validation of an early 20th century hypothesis. Naturwissenschaften 93, 557-564.

Shuman, B., Webb III, T., Bartlein, P., Williams, J.W., 2002. The anatomy of a climatic oscillation: vegetation change in eastern North America during the Younger Dryas chronozone. Quaternary Science Reviews 21, 1777-1791.

Shuman, B., Bartlein, P., Webb III, T., 2005. The magnitudes of millennial- and orbitalscale climatic change in eastern North America during the Late Quaternary. Quaternary Science Reviews 24, 2194-2206. 
Signor III, P.W., Lipps, J.H., 1982. Sampling bias, gradual extinction patterns and catastrophes in the fossil record. Geological Society of America Special Paper 190, 291-296.

Stafford Jr., T.W., Harc, P.E., Currie, L.A., Jull, A.J.T., Donahue, D., 1991. Accelerator radiocarbon dating at the molecular level. Journal of Archaeological Sciences 18, 35-72.

Stuart, A.J., 1991. Mammalian extinctions in the late Pleistocene of northern Eurasia and North America. Biological Review 66, 453-562.

Stuart, A.J., Kosintsev, P.A., Higham, T.F.G., Lister, A.M., 2004. Pleistocene to Holocene extinction dynamics in giant deer and woolly mammoth. Nature 431, 684-689.

Stuiver, M., Polach, H.A., 1977. Discussion. Reporting of ${ }^{14} \mathrm{C}$ data. Radiocarbon 19 , 355-363.

Stuiver, M., Reimer, P.J., 1993. Extended ${ }^{14} \mathrm{C}$ database and revised CALIB radiocarbon calibration program. Radiocarbon 35, 215-230.

Stuiver, M., Grootes, P.M., Braziunas, T.F., 1995. The GISP2 $\delta^{18} \mathrm{O}$ climate record of the past 16,500 years and the role of the sun, ocean, and volcanoes. Quaternary Research 44, $341-354$
Swinehart, A.L., Parker, G.R., 2000. Palaeoecology and development of peatlands in Indiana. American Midland Naturalist 143, 267-297.

Swinehart, A.L., Richards, R.L., 2001. Palaeoecology of a northeast Indiana wetland harboring remains of the Pleistocene giant beaver (Castoroides ohioensis). Proceedings of the Indiana Academy of Sciences 110, 151-166.

Thomas, E.S., 1952. The Orleton Farms Mastodon. Ohio Journal of Science 52, 1-5.

Veltre, D.W., Yesner, D.R., Crossen, D.J., Graham, R.W., Coltrain, J.B., 2008. Patterns of faunal extinction and paleoclimatic change from mid-Holocene mammoth and polar bear remains, Pribilof Islands, Alaska. Quaternary Research 70, 40-50.

Waguespack, N.M., Surovell, T.A., 2003. Clovis hunting strategies, or how to make out on plentiful resources. American Antiquity 68, 333-352.

Waters, R.R., Stafford Jr, T.W., 2007. Redefining the Age of Clovis, implications for the peopling of the Americas. Science 315, 1122-1126.

Woodman, N., Branstrator, J.W., 2008. The Overmyer mastodon (Mammut americanum) from Fulton County. Indiana. American Midland Naturalist 159, 125-146.

Wright Jr, H.E., 2006. Climate and biota of eastern North America. In: Ubelaker, D.H. (Ed.), Handbook of North American Indians. Vol. 3. Environment, Origins, and Populations. Smithsonian Institution, Washingon, DC, pp. 99-109. 